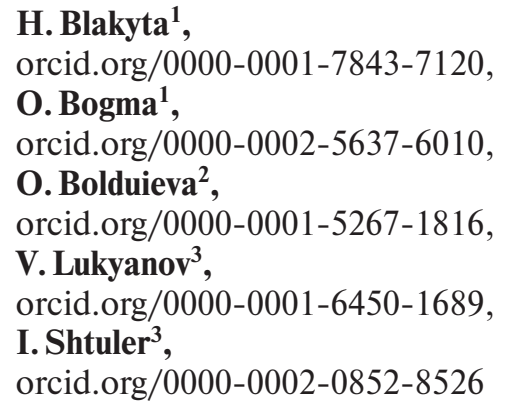

1 - Kyiv National University of Trade and Economics, Kyiv, Ukraine; e-mail: o.bogma@knute.edu.ua 2 - Zaporizhzhia National University, Zaporizhzhia, Ukraine 3 - National Academy of Management, Kyiv, Ukraine

\title{
MODELING ENTERPRISES’ ECONOMIC SECURITY IN CRISIS CONDITIONS
}

Purpose. To create a mathematical model for assessing, analyzing and forecasting the economic security of the enterprise in a crisis. To create an algorithm for assessing the levels of economic security.

Methodology. In the scientific research, the results of which are given in the presented article, general and special methods of cognition were used. The method of logical generalization is used to substantiate the relevance of the topic, purpose and objectives of the study, to determine the essential features of indicators of economic security of the enterprise. The method of comparative analysis, quantitative and qualitative comparison is used to identify an integrated indicator that correlates with the characteristics of economic security and to provide analytical and predictive results of profitability of all activities of the enterprises of the industry and on its separate branches. The method of mathematical formalization is used for the formation of a mathematical model and algorithm for assessing the level of threat to the economic security of the enterprise.

Findings. It is proposed to create a mathematical model by integrating individual blocks that use different mathematical approaches. This model is designed for analytical study on various aspects of economic security of the enterprise. Algorithms are proposed for estimating the levels of economic security (critical, dangerous, unsatisfactory, satisfactory, optimal ones) and also determining them using an integrated indicator that characterizes these levels; finding its deterministic, probabilistic and fuzzy components; a step-by-step increase in the relevance of the analysis of the level of economic security. It is also proposed to compare the effects of the crisis on enterprises in different industries and to gradually calculate integrated indicators in the areas of economic security for a homogeneous group of enterprises selected by industry, size and region. This provides an opportunity to see more broadly the threats and depth of the crisis and to implement measures to neutralize its consequences more effectively.

Originality. The mathematical model for assessing and forecasting the economic security of enterprises in crisis conditions has been created. It is proposed to conduct a permanent rapid analysis and forecast of the impact of the crisis on the economic security of the enterprise using a standardized integrated index of economic security. An algorithm of step-by-step increase in relevance of the analysis of the level of economic security is introduced.

Practical value. The developed mathematical apparatus can be used both for scientific research on various aspects of economic security of enterprises, and for practical purposes - to predict the impact of the consequences of the economic crisis and implement measures to prevent them. Using this mathematical apparatus, the analysis and forecast of profitability of industrial enterprises as a whole and by its individual branches were carried out. The results of this analysis can be used by the management of small, medium and large enterprises to develop production plans in a crisis.

Keywords: economic security of enterprise, impact of crisis, mathematical model, prognostication

Introduction. The economic security of the enterprise guarantees its viability. Monitoring and subsequent analysis of the emergence or change in trends of internal and external threats and risks of financial and economic activities of enterprises, finding means to neutralize them or reduce the impact of their consequences are the key to this guarantee.

There are still controversies about the effectiveness of the implemented methods of assessment and analysis of economic security. There is no model of such an assessment that would fully meet the practical needs. Scientists have insufficiently studied the problem of quantitative assessment of the impact of risk factors and algorithms for analyzing economic security. This prevents the introduction of effective crisis prevention measures. In the conditions of economic crisis, growing instability, reduction of sales volumes, and threatening state of the financial system lead to reduction of production volumes, decrease in contractual discipline, and slowdown in payments which cause extreme ways of functioning of enterprises. This, in turn, leads to the destruction of the resource base of the enterprise, the formation of incorrect management decisions, which exacerbates the negative impact of the crisis. That is, the onset of the crisis should change the approaches to methods for assessing and analyzing economic security. When in the conditions of stability, the competitiveness of the enterprise

(C) Blakyta H., Bogma O., Bolduieva O., Lukyanov V., Shtuler I., 2021 can be chosen as the main indicator of economic security, in the conditions of crisis the question arises how close to bankruptcy an enterprise is. All signs of the crisis are present in Ukraine today. In particular, there is an increase in the share of unprofitable enterprises [1]. But what is worse is the expectation of a worsening economic situation. Thus, the Economic Sentiment Indicator $\left(2^{\text {nd }}\right.$ quarter of 2020 to the same period in 2019 ) is $63.9 \%$, which is the worst indicator in recent years (State Statistics Service of Ukraine, 2020). The indicator of business confidence in the processing industry during this period decreased 5.13 times, in retail trade -3.94 times, in the service sector -29 times. There is a need for effective management for the formation of economic security of enterprises in such conditions.

Literature review. Problems of economic security of enterprises have been studied by many scientists. Shmaliy's scientific work proposes a generalized scheme for the formation of economic security [2]. Oliynyk [3] studied the influence of market conditions on the organization of the process of economic security of enterprises. Nazarova, et al. [4] considered the methodology of structural and functional aspects of this problem. Bogachevska and Alieksieieva [5] focus on the economic security of industrial enterprises. Sukhanov [6] considered the same problems but for agricultural enterprises. Bursariev [7] did the same for the fuel and energy complex. Detailed accounting and analytical support of economic security man- 
agement is considered by Chukurna, et al. [8]. Dub [9] investigated the economic security of enterprises using a systems approach. Cherevko, et al. [10] considered strategic management of financial and economic security as a direction of management. An interesting analytical report which examines the relationship between economic and national security is made by Retter, et al. [11]. Pasenchenko and Zinchenko [12] built a model of economic security of the enterprise using the method of hybrid fuzzy neural networks. Shynkar, et al. [13] substantiates the fact that the effectiveness of economic security for specific industries depends on the quality of the information base of the analysis. In [14] the mathematical tool for calculation of indicators of efficiency of management of economic safety of the enterprise is offered. Some elements of this mathematical approach are used for the presented scientific work. Bilan, et al. [15] developed a system of regional indicators of economic security. Frolova and Rozhenko [16] studied models of methodological approaches for assessing economic security. Liezina, et al. [17] assessed the impact of financial and market components of economic security. In [18, 19] economic security is considered as a dynamic characteristic of the enterprise.

Unsolved aspects of the problem. The presented review of the literature proves that scientists have created a wide range of scientific papers on the issue of economic security of the enterprise.

But there are still discussions about the criteria and indicators of economic security. There are also no algorithms and mathematical models for assessing the levels of economic security of the enterprise, which, on the one hand, are consistent with the basic theoretical and regulatory provisions, and, on the other hand, would meet the requirements of practitioners. There is still a lack of mathematical models that would allow creating reliable forecasts of levels of economic security, which would allow practitioners to develop tactics and strategies to reduce the impact of the crisis on the enterprise.

Purpose. To create a mathematical model for assessing, analyzing and forecasting the economic security of the enterprise in crisis conditions and form an algorithm for assessing the levels of economic security.

Methods. In the scientific research, the results of which are given in the presented article, general and special methods of cognition were used. The method of logical generalization is used to substantiate the relevance of the topic, purpose and tasks of the study, to determine the essential features of economic security of the enterprise. The method of comparative analysis, quantitative and qualitative comparison was used to identify an integrated indicator that correlates with the characteristics of economic security and to provide analytical and forecast results of profitability of all activities of the enterprises of the industry and on its separate branches. The method of mathematical formalization was used for the formation of a mathematical model and algorithm for assessing the level of threat to the economic security of the enterprise.

Results. The use of significant amounts of information to analyze and forecast the economic security of enterprises, the so-called big data, requires a significant amount of computer resources and time. This creates an undesirable time lag before the development of tactics and strategies to reduce the impact of the crisis on the enterprise, the application of localization measures that reduce the effects of the crisis. Therefore, there is a need to use a single, universal integrated indicator to conduct a rapid test to identify the threat and the direction of its trend. And only after that, for the detailed analysis, application of the whole complex of the parameters takes place. The integrated index of economic security was used as such an indicator (In: About the statement of Methodical recommendations concerning calculation of level of economic safety of Ukraine [20]). As this indicator is standardized, the execution of calculations is greatly simplified and accelerated. The value of the economic security index of previous periods is given by the
State Statistics Service. This allows to quickly and efficiently assessing the level and direction of external threats to the economic security of the enterprise.

The same mathematical model was used to assess the level of internal threat as for the analysis and prediction of the influence of external factors, with a corresponding change in the set of components, and the subsequent assessment of their weight using factor analysis.

Even the enumeration of the standardized components of the integrated economic security index [5] (Tables 1 and 2) indicates the comprehensiveness of the security assessment if it is used. It is proposed to rank safety levels as follows: critical, dangerous, unsatisfactory, satisfactory, and optimal ones.

The following approach is proposed to assess the level of economic security of the enterprise. The assessment is based on indicators combined into the following groups: volume, structure, dynamics, ratio and weight of each component of economic security of the enterprise, i.e., use of labor, financial, material, intangible resources, efficiency and safety of management, production and sales. Next, we find an integrated indicator for each component of economic security and analyze its changes. When approaching the value of the indicator to the limit of the safety interval, we form proposals to reduce the risks by ranking according to the degree of impact on the level of economic security (Fig. 1).

Calculation of the integrated indicator () of internal economic security, taking into account each $j^{\text {th }}$ component is as follows (In: About the statement of Methodical recommendations concerning calculation of level of economic safety of Ukraine [20])

$$
I=\sum_{m} d_{m} \sum_{j}^{n} d_{j} y_{j},
$$

where $m=1,2,3, \ldots$ is sphere of economic security; $d_{j}, d_{m}$ are weighting factors, which, respectively, determine the contri-

Table 1

Weights of the components of the integrated index of economic security

\begin{tabular}{|l|c|}
\hline \multicolumn{1}{|c|}{ The sphere of economic security } & Weighting factor \\
\hline Macroeconomic & 0.1005 \\
\hline Production & 0.0769 \\
\hline Financial & 0.1127 \\
\hline Investment & 0.0939 \\
\hline Externally economic & 0.0901 \\
\hline Scientific and technological & 0.1183 \\
\hline Social & 0.0808 \\
\hline Demographic & 0.0836 \\
\hline Energy & 0.1324 \\
\hline Food & 0.1108 \\
\hline
\end{tabular}

Table 2

Weights for calculating financial security

\begin{tabular}{|l|c|}
\hline \multicolumn{1}{|c|}{ Components of financial security } & Weighting factor \\
\hline Banking & 0.1723 \\
\hline For the non-banking financial market & 0.1068 \\
\hline Debt & 0.1746 \\
\hline Budget & 0.2023 \\
\hline Currency & 0.1686 \\
\hline Monetary & 0.1753 \\
\hline
\end{tabular}




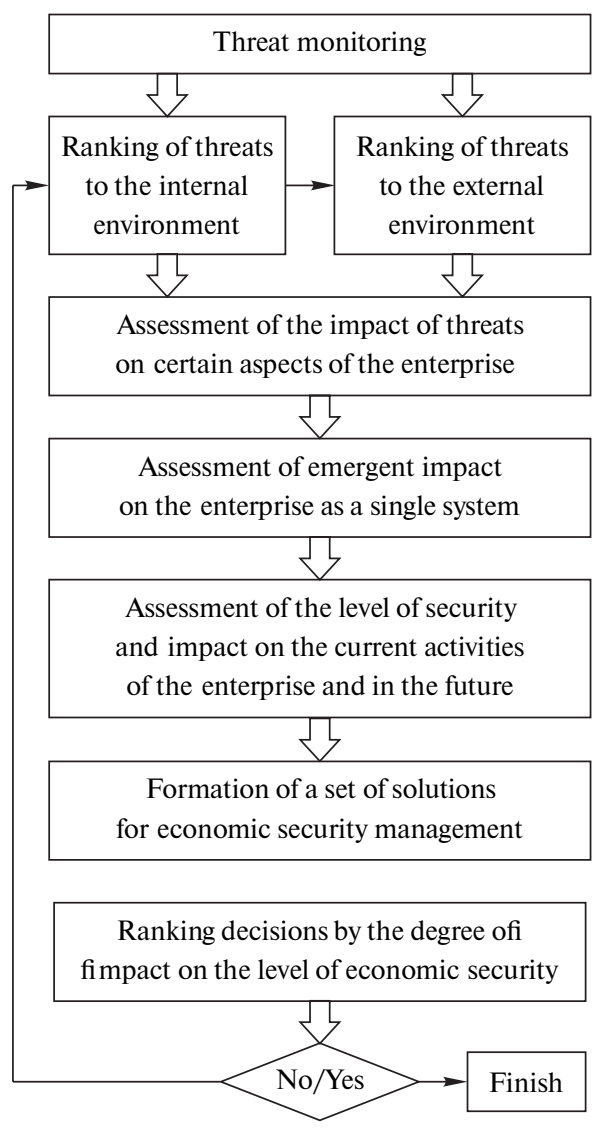

Fig. 1. Algorithm for assessing the levels of economic security and ranking decisions by the degree of impact on the level of security

bution of the $i^{\text {th }}$ indicator to the mentioned components and to the integrated indicator of internal economic security.

The algorithm for assessing the levels of economic security and ranking decisions by the degree of impact on the level of security is formed as a module of the decision-making system and the formation of tactics and strategies to reduce the impact of crises on the enterprise.

Mathematical model for assessment and analysis of economic security of the enterprise in crisis conditions. The mathematical model was formed of several blocks that use different mathematical approaches. The first block is designed to analyze the basic indicators of economic security, including the integrated indicator, the approximation of data from previous periods and the formation of a forecast for future times. Polynomial approximation was used to analyze the data of past periods. It is the polynomial approximation that makes it possible to form a universal and convenient representation of data in the form of polynomials of arbitrary degree for further use. To predict the levels of economic security for the next time, an autoregressive model was used using the moving average method.

$$
\gamma_{t}=\sum_{k=1}^{p} a_{i} \gamma_{t-k}+\varepsilon_{t},
$$

where $\gamma$ is an indicator to be predicted for the coming times; $t$ is the limit of the time interval of the forecast; $k=1,2,3, \ldots, p$ is time interval index, is a random component.

The results of the study using the methods of comparative analysis, logical generalization, quantitative and qualitative comparison. The first thing we need to do is to show the changing value of the integrated index of economic security over time (Fig. 2) (State Statistics Service of Ukraine, 2020).

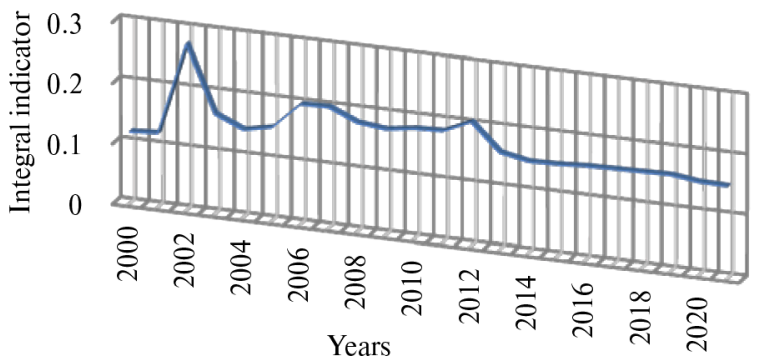

Fig. 2. Changing the value of the integrated index of economic security over time

We use the data from Fig. 2 and the obtained equation for determining the value of the integrated index of economic security over time

$$
\gamma=-0.000003 x^{4}+0.0002 x^{3}-0.0036 x^{2}+0.03 x+0.1068 .
$$

A comprehensive assessment of the economic security of the enterprise requires the analysis of a significant number of parameters that characterize various aspects of internal and external threats - quantitative, qualitative, deterministic, stochastic, fuzzy variables. Some techniques simplify the representation of fuzzy variables as qualitative or even probabilistic. This is unjustified.

The application of the fuzzy set method makes it possible to determine the degree of approach to the critical level of economic security in the presence of a set of variable fuzzy indicators that do not have a rigidly defined numerical estimate, but only intervals of change or direction of change [14]. The first step of the algorithm for applying the fuzzy set method is to determine fuzzy variables in sets of variables that describe each component of each of the areas of economic security of the enterprise. Next, the numerical values of the boundaries of the spatial regions of change in these indicators are determined. It is advisable to rank the values of the limits of change in fuzzy indicators according to the following gradation: low, optimal, high level of the indicator. This will speed up the current analysis.

To avoid inconsistencies in the use of different mathematical approaches to the calculation of deterministic, probabilistic and fuzzy components in integrated indicators, calculations were performed separately for each of the mathematical approaches, and the final value of the integrated indicator was calculated additively by taking into account the weight of each component for each of the mathematical approaches. Standard methods and algorithms were used to find the deterministic and probabilistic components.

Mathematical formalization of the use of the fuzzy set method was performed as follows. Fuzzy parameters were represented as a limited set $\langle N, \theta, \tilde{W}\rangle$, where $N$ is the value of $z$ fuzzy variables; $\theta$ is the range of their definition. Next, we determined the fuzzy set $\tilde{W}=\left\{\vartheta, \mu_{w}(\vartheta)\right\}$, where $\mu_{\tilde{v}}(\vartheta)$ is the membership function of fuzzy variables $\vartheta$. The next step was to use the standard apparatus of Boolean algebra with finding the perfect disjunctive normal form (dnf) of the Boolean function for a certain set of parameters. When the complete set $z$ of fuzzy variables could not be found, the minimum disjunctive normal form was formed and the integral exponent for fuzzy variables was the search for dnf with the minimum number of parameters $N$

$$
N=\sum_{z} r_{i}
$$

where $r_{i}$ is a rank of conjunction.

The perfect disjunctive normal form is known to represent a set of conjunctions that are connected by disjunctive signs, i.e., in mathematical form

$$
\vartheta_{1} \wedge \vartheta_{2} \wedge \vartheta_{3} \wedge \ldots \vartheta_{z}
$$


To finally obtain the integral exponent, we used the algebraic representation of the normal form in the presence of a perfect disjunctive normal form in the form of a polynomial, the coefficients of which are zero and one.

The general algorithmic approach is based on the principle of integration of separate blocks. The following algorithm of step-by-step increase in relevance of the analysis of the level of economic security for effective and fast introduction of anticrisis measures is offered. It was taken into account that the effect of the economic crisis is primarily external risks to the economic security of the enterprise.

For the rapid test of external threat trends, a change in the value of the integrated economic security index is permanently predicted. Further, in the areas of economic security, integrated indicators are calculated, whose components are selected according to the weight determined by factor analysis. These indicators are calculated in stages for a homogeneous group of enterprises selected, first by industry, then, from those - by size, then, from those, by region. It is also desirable to compare the effects of the crisis on enterprises in different industries. This will make it possible to assess and, in future, to analyze various aspects of the threat (sectoral, regional, and so on). An example of such an analysis is given in Figs. 3-6.

The next stage of the algorithm is the correlation of external threats with internal and, later, appropriate step-by-step analysis of internal threats. Factors and spheres of influence of internal threats to economic security are revealed individually for each enterprise by means of the factor analysis.

One of the defining indicators of the level of economic security of enterprises is the level of profitability of their activities. Taking into account the impact of the crisis, the analysis of indicators of previous years and the forecast for the next years of profitability of industrial enterprises separately for large, medium and small enterprises were carried out (Fig. 3).

The significance of the impact of the crisis can be assessed by the degree of change in the index being analyzed. Even a quick look at Fig. 3 indicates the uneven impact of the crisis of

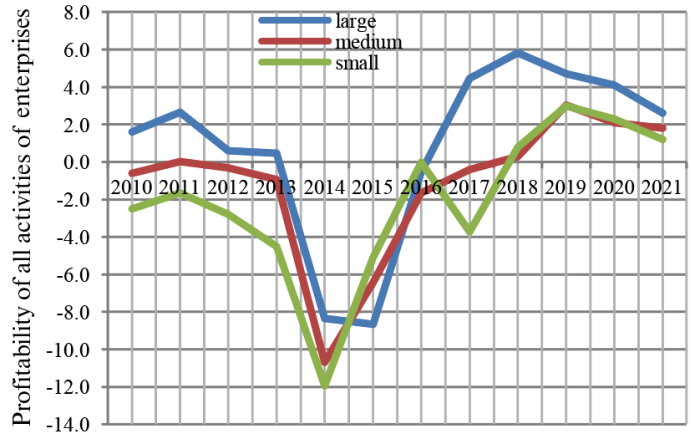

Fig. 3. Analysis and forecast of profitability of all activities of industrial enterprises from year to year

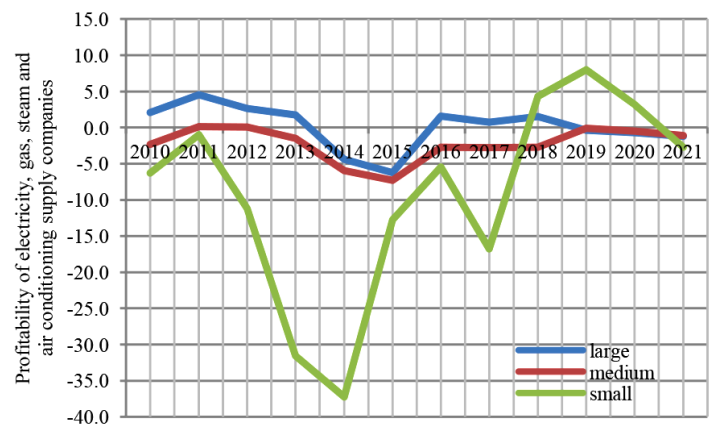

Fig. 4. Analysis and forecast of profitability of all activities of electricity, gas, steam and conditioned air supply companies by year

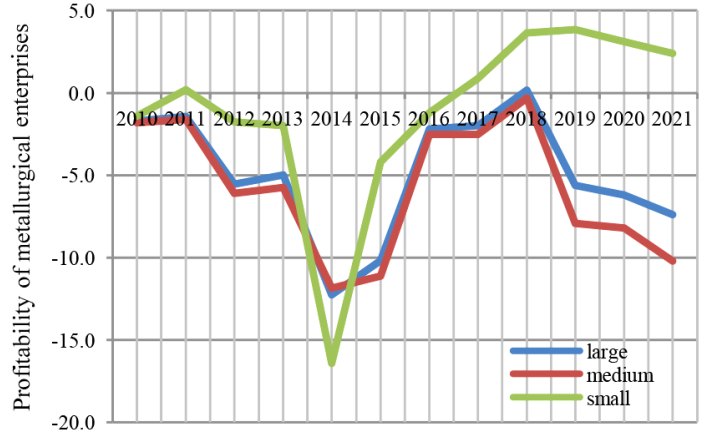

Fig. 5. Analysis and forecast of profitability of metallurgical enterprises by year

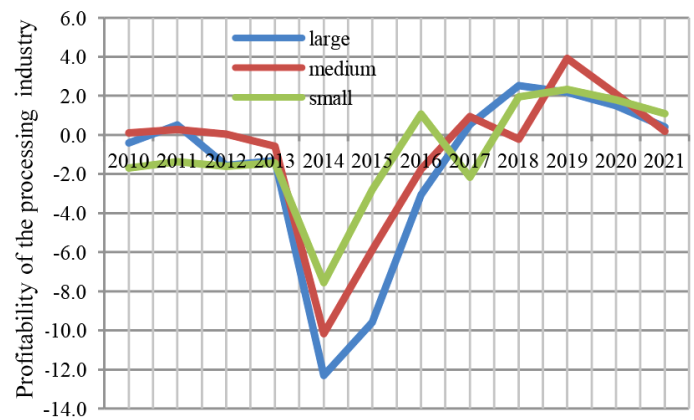

Fig. 6. Analysis and forecast of profitability of enterprises of the processing industry by year

2012-2016 on different groups of enterprises (large, small, medium) and the impact of the current crisis on the profitability of industrial enterprises. Small businesses are much more affected by the crisis, medium enterprises are affected less, and large ones are affected even less. The decline in the profitability trend, which continues today and is projected for future periods, began in 2018 (Fig. 3). Next, according to the above algorithm, we conduct a sectoral analysis.

Fig. 4 shows that small, medium and large enterprises in the field of electricity, gas, steam and conditioned air are characterized by different lags in the time affected by the crisis. Common to Figs. 3 and 4 is the fact that an anticipatory decline in profitability for small businesses is projected in 2021.

The decline in profitability for small enterprises of metallurgical production (Fig. 5) is smaller than for large and medium ones, but they can feel the depth of the crisis more (by analogy with 2014). Medium-sized metallurgical enterprises are the most vulnerable to the current crisis.

As for processing enterprises (Fig. 6), the impact of the crisis will be more pronounced for large enterprises. But medium-sized enterprises will reach levels of large fall in profitability with a certain lag in time. The industry difference is that the profitability trends for the enterprises of the industry can be radically opposite. This is evidenced by the analysis of the situation in 2017 (Fig. 6).

Analysis of the above data in Figs. 3-6 indicates that the impact of the crisis will be felt by enterprises of all industries, but trends, rates and lags over time will be different for enterprises of different industries, different production volumes and this should be taken into consideration for careful comparative analysis while studying the effect of the crisis on the economic security of the enterprise.

Conclusions. The mathematical model using integrated blocks which is intended for estimation, the analysis and the forecast of economic safety of the enterprise in crisis conditions is created. The mathematical model combines different mathematical approaches, in particular, to predict the performance of subsequent periods $A R M A(p, q)$ model is used using 
the moving average method. Algorithms for estimating the levels of economic security are detailed, taking into account the integrated indicator that characterizes this level together with deterministic, probabilistic and fuzzy components. It is proposed to use an integrated index of economic security for express analysis and forecast of the impact of the crisis on the economic security of the enterprise. This analysis is facilitated by the presence of standardized methods for calculating the specified integrated index and open statistics on it. An algorithm of step-by-step increase of relevance in the analysis of the level of economic security for effective and fast implementation of anti-crisis measures is also implemented. To do this, it is proposed to gradually calculate the integrated indicators in the areas of economic security for a homogeneous group of enterprises selected by industry, size, and region.

For a more complete assessment and forecast of the impact of the crisis on the economic security of a particular enterprise, it is recommended to compare the effects of the crisis on enterprises in different industries. An example of analytical research and forecast of profitability of industrial enterprises as a whole and by separate branches is given: metallurgical production; supply of electricity, gas, steam and conditioned air and the processing industry. This analysis was conducted in detail for companies with different production volumes, which allowed assessing the impact of the crisis of 2012-2016 and the current crisis, the risks of which were experienced by companies in various industries in 2018-2019. The application of the method of analogies between these crises allowed us to predict a certain course of the crisis in the coming years for small, medium and large enterprises in various industries.

\section{References.}

1. Rozin, V. (2021). From Engineering and Technological Process to Post-Cultural Technology. Future Human Image, 15, 99-109. https:// doi.org/10.29202/fhi/15/9.

2. Shmaliy, L. V. (2019). Economic safety of enterprise: current problems of the supply. Economics. Management. Business, 1(27), 123-129. https://doi.org/10.31673/2415-8089.2019.012329.

3. Oliynyk, T. (2019). Methodical aspects of economic safety assessment of enterprises in market conditions. Ekonomika ta derzhava, 10, 69-72. https://doi.org/10.32702/2306-6806.2019.10.69.

4. Nazarova, K., Mysiuk, V., Gordopolov, V., Koval, V., \& Danilevičiené, I. (2020). Preventional audit: implementation of SOX control to prevent fraud. Business: Theory and Practice, 21(1), 293-301. https:// doi.org/10.3846/btp.2020.11647.

5. Bogachevska, I., \& Alieksieieva, K. (2020). The Techno-Humanitarian Balance and Modernity. Philosophy and Cosmology, 25, 78-87. https://doi.org/10.29202/phil-cosm/25/7.

6. Sukhanova, A. V. (2019). Main components and principles of economic security of agrarian enterprises. Ukrainian Journal of Applied Economics, 4(2), 97-103. https://doi.org/10.36887/2415-8453-20192-11.

7. Bursariev, V. (2019). Characteristics of main components of the economic security system of the fuel and energy complex. Scientific Papers (Ukrainian Academy of Printing), 1(58), 127-142. https://doi. org/10.32403/1998-6912-2019-1-58-95-102.

8. Chukurna, O., Nitsenko, V., Kralia, V., Sahachko, Y., Morkunas, M., \& Volkov, A. (2019). Modelling and Managing the Effect of Transferring the Dynamics of Exchange Rates on Prices of MachineBuilding Enterprises in Ukraine. Polish Journal of Management Studies, 19(1), 117-129. https://doi.org/10.17512/pjms.2019.19.1.09.

9. Dub, B. S. (2016). The system of the enterprise's economic security: the concept and structure. Project management and production development, 4(60), 5-18.

10. Cherevko, O., Nazarenko, S., Zachosova, N., \& Nosan, N. (2019). Financial and economic security system strategic management as an independent direction of management. SHS Web of Conferences, 65, 03001. https://doi.org/10.1051/shsconf/20196503001.

11. Retter, L., Frinking, E. J., Hoorens, S., Lynch, A., Nederveen, F., \& Phillips, W.D. (2020). Relationships between the economy and national security: Analysis and considerations for economic security policy in the Netherlands. Wetenschappelijk Onderzoek- en Documentatiecentrum. https://doi.org/10.7249/RR4287.

12. Pasenchenko, Yu.A., \& Zinchenko, K.R. (2017). Modeling construction company strategy using game theory. Actual problems of eco- nomics and management, 11. Retrieved from http://ape.fmm.kpi.ua/ article/view/102865/97983.

13. Shynkar, S., Gontar, Z., Dubyna, M., Nasypaiko, D., \& Fleychuk, M. (2020). Assessment of economic security of enterprises: theoretical and methodological aspects. Business: Theory and Practice, 21(1), 261-271. https://doi.org/10.3846/btp.2020.11573.

14. Gochua, A., \& Zedelashvili, T. (2020). Cyber Threats and Asymmetric Military challenges In the Context of Nuclear Security: Ukrainian and International Cases Analysis. Ukrainian Policymaker, 7, 2027. https://doi.org/10.29202/up/7/3.

15. Bilan, Y., Zos-Kior, M., Nitsenko, V., Sinelnikau, U., \& Ilin, V. (2017). Social component in sustainable management of land resources. Journal of Security and Sustainability, 7(2), 107-120. https://doi. org/10.9770/issi.2017.7.2(9).

16. Frolova, L. V., \& Rozhenko, O. V. (2016). Methodical approaches to enterprise economic security assessment. Actual problems of economics, 3(177), 199-209.

17. Liezina, A., Andriushchenko, K., Rozhko, O., Datsii, O., Mishchenko, L., \& Cherniaieva, O. (2020). Resource planning for risk diversification in the formation of a digital twin enterprise. Accounting, 6, 1337-1344. https://doi.org/10.5267/i.ac.2020.8.016.

18. Pilipenko, N. M., \& Pilipenko, V. V. (2017). Economic security as a dynamic characteristic of an enterprise. Economy and society, 10, 338-342.

19. Plastun, A., Drofa, A. O., \& Klyushnik, T. V. (2019). Month of the year effect in the cryptocurrency market and portfolio management. European Journal of Management Issues, 27(1-2), 29-35. https://doi. org/10.15421/191904.

20. On approval of Methodical recommendations on the calculation of the level of economic security of Ukraine. 29.10.2013 No. 1277. Retrieved from https://zakon.rada.gov.ua/rada/show/v1277731-13\#Text.

\section{Моделювання економічної безпеки підприємств в умовах кризи}

\section{Г. В. Блакита ${ }^{1}$, О. С. Богма ${ }^{1}$, О. В. Болдуєва ${ }^{2}$, В. С. Лук'янов ${ }^{3}$, І. Ю. Штулер}

1 - Київський національний торговельно-економічний університет, м. Київ, Україна, e-mail: o.bogma@knute.edu.ua 2 - Запорізький національний університет, м. Запоріжжя, Україна

3 - Вищий навчальний заклад «Національна академія управління», м. Київ, Україна

Мета. Створити математичну модель оцінки, аналізу та прогнозу економічної безпеки підприємства у кризових умовах. Сформувати алгоритм оцінювання рівнів економічної безпеки.

Методика. У науковому дослідженні, результати якого надані у представленій статті, були використані загальні та спеціальні методи пізнання. Метод логічного узагальнення застосовано для обгрунтування актуальності теми, мети й завдань дослідження, для визначення сутнісних ознак показників економічної безпеки підприємства. Метод порівняльного аналізу, кількісного та якісного порівняння - для виявлення інтегрального покажчика, шо корелює з характеристиками економічної безпеки та надання аналітичних і прогнозних результатів рентабельності всієї діяльності підприємств промисловості та за окремими її галузями. Метод математичної формалізації - для формування математичної моделі та алгоритму оцінки рівня загрози економічній безпеці підприємства.

Результати. Запропоновано створення математичної моделі інтеграцією окремих блоків, що використовують різні математичні підходи. Ця модель призначена для аналітичного дослідження різних аспектів економічної безпеки підприємства. Запропоновані алгоритми оцінювання рівнів економічної безпеки (критичного, небезпечного, незадовільного, задовільного, оптимального), визначення їх за допомогою інтегрального показника, що характеризує ці рівні; знаходження його детермінова- 
них, імовірнісних і нечітких складових; покрокового збільшення релевантності аналізу рівня економічної безпеки. Також запропоновано порівнювати впливи кризи на підприємства різних галузей і поетапно розраховувати інтегральні показники за сферами економічної безпеки для однорідної групи підприємств, обраних за галуззю, розміром, регіоном. Це надає можливість більш широко бачити загрози й глибину кризи та ефективніше впроваджувати заходи нейтралізації іiі наслідків.

Наукова новизна. Створена математична модель для оцінювання та прогнозування економічної безпеки підприємств у кризових умовах. Запропоновано проведення перманентного експрес-аналізу та прогнозу впливу кризи на економічну безпеку підприємства за використання унормованого інтегрального індексу економічної безпеки. Упроваджено алгоритм покрокового збільшення релевантності аналізу рівня економічної безпеки.
Практична значимість. Розроблений математичний апарат може бути використаний як для наукових досліджень різних аспектів економічної безпеки підприємств, так і у практичних цілях - для прогнозування впливу наслідків економічної кризи та впровадження заходів для їх запобігання. За використання цього математичного апарату проведено аналіз і прогноз рентабельності діяльності підприємств промисловості в цілому та за окремими ії галузями. Результати цього аналізу можуть бути використані менеджментом малих, середніх і великих підприємств для розробки планів виробництв в умовах кризи.

Ключові слова: економічна безпека підприємства, вплив кризи, математична модель, прогнозування

Recommended for publication by M.V.Vereskun, Doctor of Economic Sciences. The manuscript was submitted 23.01.21. 